\title{
THE GuTS OF A TORTS CLASS
}

\author{
Graeme W Austin*
}

As a tribute to Professor Bill Atkin's unswerving dedication to the teaching of the law of torts, this article makes a few personal observations about tort law teaching at Victoria University of Wellington. The article's focus is the craft of so-called Socratic teaching, which, broadly described, involves inviting students to participate in classroom dialogue that scrutinises the quality of judicial reasoning. The article links that endeavour to the Law School's obligation to act as a conscience and critic of society, and to its commitment to inculcate values associated with the rule of law.

\section{INTRODUCTION}

Some might read the title as suggesting that the law of torts is a subject for which all is not well. Whatever insights might be derived from picking over entrails, exposing the "guts" of anything implies that the subject enjoys, to say the least, somewhat indifferent health. For a festschrift in honour of Professor Bill Atkin, a much-beloved teacher who has introduced generations of secondyear Victoria University of Wellington law students to the intricacies of tort law, ${ }^{1}$ this could seem like something of a downer. Later, however, I attempt to give a more positive spin to the idea. Using "guts" in its more figurative sense, this article offers some personal observations about what might be especially important in the teaching of tort law.

The body of tort law does at times appear to be infirm. The accident compensation system has severed from the torts corpus most of the personal injury jurisprudence that preoccupies torts scholars and practitioners in other jurisdictions. ${ }^{2}$ The legislative scheme not only cuts off large parts

* BA(Hons); LLM, Victoria University of Wellington; LLM; JSD, Columbia University. Chair of Private Law, Victoria University of Wellington; Professor of Law, Melbourne University Law School. This article was written during a period of research and study leave from the former institution. Thanks to the editors for the invitation to contribute an article to this volume, and to Professors David McLauchlan and Ian Malkin, and to the anonymous referee for many helpful comments on an earlier draft. Thanks also to Paul ComrieThomson for careful and insightful editing. Principal thanks, of course, go to Professor Bill Atkin for providing the inspiration for this article and for being a splendid mentor over many years.

1 Professor Atkin is now also one of the authors of the leading New Zealand torts textbook, joining the authorship team with the most recent edition. Stephen Todd and others The Law of Torts in New Zealand (6th ed, Thomson Reuters, New Zealand, 2013).

2 Accident Compensation Act 2001, s 317. See generally Stephen Todd "Krinlock Lecture 2011: Forty Years of Accident Compensation in New Zealand" (2011) 28 TM Cooley L Rev 189. 
of negligence; the statutory bar also means that much of the New Zealand law on battery and assault has withered away. ${ }^{3}$ Even land-based torts have been largely superseded by regulatory frameworks, at both the national and local levels. ${ }^{4}$ And a quick telephone call to the "noise police" at the local city council is likely to solve some of the most immediate and prevalent nuisance issues most people are likely to confront in their ordinary lives.

Tort law must also contend with the primacy of contract in common law thinking. The privileging of private ordering certainly limits the domain in which tort may roam. To be sure, postDonoghue $v$ Stevenson, ${ }^{5}$ tort law is not entirely muscled out when any contract with any party has delimited the scope of liability. Even so, contract ideas (and ideals) can sometimes tether tort law to quite a small area, and this occurs not only when there was a contract between the actual parties: the torts chain can be yanked quite hard when something in the contractual chain ought to have governed the parties' rights and obligations. Turton $v$ Kerslake is an example. ${ }^{6}$ In addition, our online activities are increasingly mediated by contractual terms and conditions. This may further limit the relevance of tort - and possibly property as well. Where massive numbers of people agree to the same thing, the vast clustering of in personam obligations comes close to granting the offeror rights that in their aggregate are equivalent to rights in rem. Digital boilerplate "to the power of $\mathrm{n}$ " can seem tantamount to rights against all the world. ${ }^{7}$

Additionally, consumer law ${ }^{8}$ now aspires to do a lot of the heavy lifting that tort law might otherwise be expected to do. The prescriptions and proscriptions in the Consumer Guarantees Act

3 In serious cases of intentional harms, criminal law is likely to be involved, and the payment of reparations in sentencing (Sentencing Act 2002, ss 32-38A) might have become the practical equivalent of a state-funded pursuit of a damages claim on behalf of the victim. However, the Supreme Court held in Davies $v$ Police [2009] NZSC 47, [2009] 3 NZLR 189 that the statutory prohibition in s 32(5) of the Sentencing Act 2002 against making orders for reparation in respect of which compensation may be payable under the Accident Compensation Act 2001 extends to preclude compensating a victim of crime for the shortfall between her full loss of income and the sum she received under the Accident Compensation Act 2001.

4 Rare cases raising difficult and complex issues in the land-based torts area occasionally slip through. $W u v$ Body Corporate 366611 [2014] NZSC 137, [2015] 1 NZLR 215 is a notable recent example.

5 Donoghue v Stevenson [1932] AC $562(\mathrm{HL})$.

$6 \quad$ RM Turton \& Co (in liq) v Kerslake [2000] 3 NZLR 406 (CA) at [7].

7 The factual contexts within which such issues arise are various. One important area is with shrink-wrap (and click-through) licences and the debate they fomented, following the influential decision of the United States Federal Court for the Seventh Circuit, in ProCD Inc v Zeidenberg 86 F 3d 1447 (7th Cir 1996). In the United States, this provoked significant controversy in the light of proposed changes to the Uniform Commercial Code, art 2B, that would have given a legislative imprimatur to contractual terms that would otherwise be unenforceable. See generally Mark A Lemley "Beyond Preemption: The Law and Policy of Intellectual Property Licensing" (1999) 87 CLR 111.

8 For a comprehensive description of New Zealand consumer law, see Kate Tokeley Consumer Law in New Zealand (2nd ed, LexisNexis, Wellington, 2014). 
1993 and the Fair Trading Act 1986 supplement and, in practice, substitute for common law obligations. In New Zealand, statutory intervention has also curtailed one of the mid-20th century's important "torts" innovations: liability for negligent misstatements. In the pre-contractual context, liability for statements that might have established a Hedley Byrne $e^{9}$ claim has now been largely assimilated to contract. ${ }^{10}$ One might be forgiven for thinking that tort law is like the elderly greataunt one sees every year at the family Christmas: however delighted we are to see her, we are also somewhat surprised that she is still hanging on.

As is discussed in more detail below, tort law's uneasy position may be part of what makes it such a perfect vehicle for teaching and learning. Legal scholars will have recognised the title as being an homage to the brilliant 1985 law review article, The Anatomy of a Torts Class, ${ }^{11}$ by Professor Jamie Boyle, now at Duke University Law School. (Substituting "guts" for "anatomy" is not only meant to signal a certain Kiwi earthiness; the substantive significance of the term will later become apparent.) There, Professor Boyle discusses with wonderful insight and humility the many challenges that confront law teachers in the torts classroom. In this brief article, I intend to make a few observations about the relevance to New Zealand classroom practice of some of the characteristics of tort law that have been sketched above. My particular focus will be so-called Socratic teaching, which, broadly described, involves inviting students to participate in a dialogue that scrutinises the quality of judicial reasoning. ${ }^{12}$ Bill is a master at this kind of teaching, yet he is

$9 \quad$ Hedley Byrne \& Co Ltd v Heller \& Partners Ltd [1964] AC 465 (HL).

10 The Contractual Remedies Act 1979, s 6(1)(a), provides that if a party to a contract has been induced to enter into it by a misrepresentation by another party to the contract, the first party shall be entitled to damages from that other party in the same manner and to the same extent as if the representation were a term of the contract that has been broken. See David McLauchlan "Liability under Hedley Byrne for 'PreContract' Negligent Misrepresentation: A New Zealand Perspective" in Kit Barker, Ross Grantham and Warren Swain (eds) The Law of Misstatements: 50 Years on from Hedley Byrne v Heller (Hart Publishing, Oxford, 2015).

11 James Boyle "The Anatomy of a Torts Class" (1985) 34 Am UL Rev 1003. For another very insightful discussion of torts teaching, see Reg Graycar "Teaching Torts as if the World Really Existed: Reflections on Harold Luntz's Contribution to Australian Law School Classrooms" (2003) 27 MULR 677.

12 I recognise that it takes some temerity, not to say chutzpah, to champion Socratic law teaching in this way. Indeed, many scholars point out that what we describe as "Socratic", classroom discussion involving careful textual analysis, is not "Socratic" in the least. See Richard K Neumann Jr "A Preliminary Inquiry into the Art of Critique" (1988) 40 Hastings LJ 725. However, to characterise "Socratic teaching" as an exercise in mere "rhetoric", a pursuit that both Socrates and Plato despised, is an overstatement. For the reasons pursued in this article, the quality of the reasoning in legal materials has a more profound significance, itself meriting the attention paid to it in the law school classroom. As for critiques of Socratic-style teaching, the literature is vast. Socratic teaching is variously described as brutalising, dehumanising, not especially effective, and as disadvantaging women law students. For a very small sample, see Alan A Stone "Legal Education on the Couch" (1971) 85 Harv L Rev 392; Taunya Lovell Banks "Gender Bias in the Classroom" (1990) 14 So Ill ULJ 527; Russell L Weaver "Langdell's Legacy: Living with the Case Method" (1991) 36 Villa L Rev 517; and Jennifer L Rosato "The Socratic Method and Women Law Students: Humanize, Don't Feminize" (1997) 75 S Cal Rev L \& Women's Stud 37. These observations and studies should be (and are) 
no Professor Kingsfield. In the classroom as elsewhere, Bill is unswervingly decent and courteous. Rather than frightening students, he draws them into a carefully crafted discussion about the legal materials assigned for each class, and, along the way, helps them to be more articulate and more confident in their analysis of the law. The modest aim of this article is to advance a few reasons for thinking that this kind of teaching is important and useful.

To that end, this article discusses some of the things we are trying to achieve in the classroom at the Victoria Law School: what some of us do, and why we do it. A festschrift for Professor Bill Atkin is the perfect forum for reflections on pedagogical practice. In truth, a collection of articles in honour of any of my colleagues would be an apt context in which to offer some reflections on legal pedagogy. The Victoria Law School has for many generations been recognised as a place that values research as well as research-based teaching. Its faculty comprises a group of fiercely dedicated fulltime professional legal scholars who are committed to the academic mission of teaching, research, and public engagement and service.

But this festschrift is for Bill, and on this happy occasion a few passing comments about Bill's qualities as a scholar-teacher may be forgiven. Not only is Bill a nationally and internationally renowned family law academic, he is also a dedicated and expert university law teacher, having devoted most of his career to perfecting his craft. As an undergraduate law student, I enjoyed the privilege of experiencing Bill's teaching, in both torts and family law. As a postgraduate student, I benefited greatly from Bill's expert supervision of my LLM thesis; his practices continue to inform my supervision of my own postgraduate students. When I began my career as a very junior academic, Bill was a guiding and generous mentor. He continues to offer guidance to younger academics, and his expertise and deep experience enable him to do this with credibility. By example, ability, disposition and long experience, Bill exemplifies so many of the characteristics and qualities of the university-level scholar-teacher to which we should all aspire.

\section{A SCHEMATISED TORTS CLAIM (AND STATE POWER)}

Whatever their personal and professional journeys, we expect our graduates to contribute to the maintenance and flourishing of the rule of law. This will most obviously be part of the professional lives of those of our graduates who participate in law reform and policy work. Many Victoria law

taken seriously by legal academics. That said, we should also resist the facile assumption that because some so-called Socratic law teaching is bad, all such teaching should be similarly characterised. The Victoria University of Wellington Law Faculty has recently received a Report on its classroom pedagogy, focusing on so-called "Socratic teaching": Cedric Hall and Liz Jones Evaluation of Socratic Teaching in the Faculty of Law, Victoria University of Wellington: A Report to the Pro Vice-Chancellor and Dean of Law from the Centre for Academic Development (Victoria University of Wellington, March 2015) (on file with author). While the Report makes many useful observations, it does not address in detail the ethical framework within which the teaching of law occurs: that is, the Report does not acknowledge that our students are being educated in a context of a profession in which, as a result of ethical and other professional commitments, there is very little tolerance for inadequate preparation. 
graduates will contribute to, and eventually lead, policy development that will help shape the commercial marketplace, assist in the functioning of government and of civil society, and enhance the dignity of individuals and peoples. It is an important undertaking. When the rule of law becomes pallid or infirm, so too does a tolerable human existence. The responsibilities are also relevant in private lawyer-client relationships. People usually engage with the law when taking important life steps - major transactions, embarking on new business ventures or new intimate relationships. Lawyers are also called upon when things go wrong. Private clients come to lawyers holding all their tomorrows in their hands or when hoped-for tomorrows are at risk. Law demands, and legal education must encourage, an attitude of mind that acknowledges and honours the significant responsibilities many of our students will eventually shoulder. One of the key challenges for legal academics is how to bring these concerns into the classroom in ways that resonate for our students.

This can be achieved in many different ways. Diversity in pedagogical practice is one of the strengths of the university experience. In this article, I briefly sketch how these concerns might be brought into the torts classroom, ${ }^{13}$ especially in the context of teaching practice that involves detailed analysis of judicial reasoning. This takes time, and, given that classroom hours are zero sum, there are inevitably costs in terms of doctrinal coverage. But there is an important point to it. In the common law world, the general expectation that legal actors provide reasons for their decisions is, amongst other things, a crucial part of our commitment to the rule of law. ${ }^{14}$ In the classroom, when we encourage students to evaluate and critique legal reasoning, we are inviting them to participate in a practice that connects a commitment to the rule of law to students' learning endeavours. The torts class provides the perfect laboratory.

My thinking about torts teaching, and about the connection between teaching and the rule of law, begins with a schematised torts case. Party P alleges that Party D committed a legally cognisable wrong. Assume that Party P successfully invokes a viable liability theory sounding in tort, is able to prove its case, and is awarded compensatory damages, which Party D is ordered to

13 The law of torts is a common law subject. Where it is supplemented by statutes, such as the Defamation Act 1992, these statutes tend to paint with quite a broad brush. While tort law is an excellent vehicle for exploring judicial reasoning, other classes will provide students with opportunities to develop crucially important skills in statutory analysis. Law schools could perhaps do much more to equip students with the necessary skills to engage with complex legislative regimes. In United States law schools, there has been a refreshing move in recent years to provide students and teachers with textbooks that enable deeper classroom engagement with statutory and administrative regimes. See for example Lisa Heinzerling and Mark V Tushnet The Regulatory and Administrative State: Materials, Cases, Comments (Oxford University Press, Oxford, 2006). This is a development that New Zealand law schools should certainly consider emulating.

14 For an insightful commentary on this point, exploring which legal actors appropriately have this duty imposed upon them, see Matthew Groves "Reviewing Reasons for Administrative Decisions: Wingfoot Australia Partners Pty Ltd v Kocak" (2013) 35 Syd LR 627; and Jason Bosland and Ashleigh Bagnall "An Empirical Analysis of Suppression Orders in the Victorian Courts: 2008-12" (2013) 35 Syd LR 671. 
pay. What is really going on, here? A branch of the government, the judiciary, has ordered one citizen to pay money to another citizen. ${ }^{15}$ A successful torts claim can vindicate rights, but it can also profoundly alter the parties' property entitlements. Of course, legal claims seldom play out according to the scheme. Things do not usually get to this stage. Most cases settle well before a court-ordered damages award. And litigation can involve only small slivers of the process: summary judgment motions, swarms of interlocutory applications and the like are the work-a-day world of any case. Even so, it is instructive to keep the schematised case in mind: plaintiffs who pursue torts claims for damages all the way to the finish line usually expect this kind of state-sanctioned transfer of property from the defendant to be the main agenda item at the prize-giving ceremony. This is often a key point of the whole endeavour.

Individuals tend not to like giving up their stuff, ${ }^{16}$ so, for unsuccessful defendants, this kind of state action can be painful. From a societal perspective, the implications of any kind of state-ordered transfer of property from one citizen to another are even more serious. However rationalised, property is a serious business. Whatever one's favourite flavour of property theory - Lockean, ${ }^{17}$ Hegelian, ${ }^{18}$ Aristotelian, ${ }^{19}$ collectivist, individualist, take your pick - we regard, or ought to regard, property entitlements as being very important to societal organisation, and to individual and community welfare. For Lockeans, property entitlements are a key part of the social contract. The more Hegelian-minded of us acknowledge that our relationships with things constitute part of who we are: they are of us, and we are of them. Aristotelians see property as an expression of the commitments and responsibilities we owe to each other that render social life tolerable. Property thinking weaves together in complex web some very basic ideas about the role of government,

15 Underlying this "transfer" are, in many cases, likely to be electronic funds transfers between banks. In a strict legal sense, underlying the "property" interests being transferred are alterations in the parties' choses in action vis-à-vis their relationship with their respective banks. See Foskett v McKeown [1998] Ch 265 (CA).

16 Even where it might be more rational to do so. The endowment effect described by behavioural economists suggests that the level of compensation most people seek for being deprived of property significantly exceeds the sum they expect to pay to acquire the same property. See Jack L Knetsch "The Endowment Effect and Evidence of Nonreversible Indifference Curves" (1989) 79 Am Econ Rev 1277 at 1277 (describing a number of famous experiments demonstrating the impact of prior entitlements on the assessment of value).

17 For a useful survey, see Karl Widerquist "Lockean Theories of Property: Justifications for Unilateral Appropriation" (2010) 2(1) Public Reason 3.

18 Professor Margaret Radin's work was instrumental in introducing Hegelian conceptions of property law to modern Anglo-American property law thinking. See Margaret Radin Contested Commodities (Harvard University Press, Cambridge (Mass), 1996); and Margaret Radin Reinterpreting Property (University of Chicago Press, Chicago, 1993).

19 Professor Gregory Alexander's scholarship is prominently associated with Aristotelian (or "human flourishing") rationalisations for property rights. See for example Gregory S Alexander "Ownership and Obligations: The Human Flourishing Theory of Property" (2013) 43 HKLJ 451. 
community, personal fulfilment and identity. For New Zealanders, the profundity of these relationships is heard and felt in recitations of whakapapa. In the western legal tradition, all of this receives its most elaborate theorising in the United States constitutional context. Private property is regarded as sacrosanct because, amongst other things, it provides a bulwark against government interference with basic liberties. ${ }^{20}$ United States constitutional jurisprudence (and large dollops of its foundational political thinking) is very clear. Property protections help keep the citizenry safe from tyranny. They are a subset of fundamental liberty interests, an idea that is captured by human rights instruments that articulate basic obligations to protect property. ${ }^{21}$ Back in the Anglo common law world, we can sense these ideas in some courts' squeamishness about the remedial constructive trust. $^{22}$ It is one thing to recognise where property interests lie; it is quite another, apparently, to create property interests by judicial action. ${ }^{23}$

Of course, the state alters property entitlements all the time. A number of things make this acceptable: a legislative mandate, due process (in some jurisdictions, constitutional due process) and an independent judiciary are all important. In many contexts, the reasons for any interference with vested interests are also crucial. In the common law tradition, we expect legal actors to justify and explain what they are doing and why they are doing it. In the schematised torts case, this means explaining why Party D is to be made to cough up its property to Party P. Given the salience of

20 The Fifth Amendment to the United States Constitution provides in material part: "No person shall ... be deprived of life, liberty, or property, without due process of law; nor shall private property be taken for public use, without just compensation." It applies to the federal government and to the states through the due process clause of the Fourteenth Amendment. It is widely accepted that the framing generation viewed the security of property as one of the fundamental purposes of government. Compare comments of James Madison ("The primary objects of civil society are the security of property and public safety") and Alister Hamilton ("One great objt. of Govt. is personal protection and the security of Property") in Max Farrand (ed) The Records of the Federal Convention of 1787 (Yale University Press, New Haven, 1934) vol 1 at 147 and 302.

21 See for example the Universal Declaration of Human Rights GA Res 217, III (1948), art 17.

22 Westdeutsche Landesbank Girozentrale v Council of the London Borough of Islington [1996] 2 AC 669 (HL) (where Lord Browne-Wilkinson noted the differences between English law, which does not recognise a remedial constructive trust, and that of New York, which does). See also Bathurst City Council v PWC Properties Pty Ltd [1998] HCA 59, (1998) 195 CLR 566 at [41], in which the High Court of Australia, without actually overturning earlier cases, most predominantly Muschinski v Dodds (1985) 160 CLR 583 (HCA), that had recognised a remedial constructive trust, suggested that it should be a remedy of last resort. But compare John Alexander's Clubs Pty Ltd v White City Tennis Club Ltd [2010] HCA 19, (2010) 241 CLR 1 (acknowledging the remedial constructive trust, albeit where not required by the factual context). In the New Zealand context, an insightful summary of these issues is provided in Commonwealth Reserves I v Chodar [2001] 2 NZLR 374 (HC).

23 Many theorists would of course contest this distinction. The distinction between identifying and creating property rights is a blurry one, to say the least. For an important early statement of these ideas, see Roscoe Pound "The Progress of the Law, 1918-1919" (1920) 33 Harv L Rev 420 at 420-421 (articulating, only to reject, the distinction between substantive and remedial trusts). 
property interests in the modern state, and their importance to the social order and personal fulfilment, the reasons had better be good ones. (So much is true even without ranking the importance of state action: after all, there should also be exceptionally good reasons for interfering with personal freedom!) Without adequate reasons, when a branch of government requires one citizen to hand over property to another citizen it bespeaks incompetence at best - but it very quickly comes to feel like corruption or tyranny, or both. Many nations, ours included, are still working through the present implications of a painful past in which this sort of thing was fairly routine. And there are still places in which people are subject to arbitrary state action that alters vested property rights without adequate reasons or due process. Those who have lived under such regimes know just how enervating and demoralising this can be.

This brief excursion into basic property theory is meant to highlight what really is at stake in the schematised torts case. When we scrutinise judicial reasoning, this is not just an exercise in abstract logic. Something very important is at stake for society and for the parties - either directly, or, depending on the character of the defendant, at one step removed, as shareholders, ratepayers and taxpayers. In the New Zealand context, Professor Robert Cover's famous statement that the work of legal actors "takes place in a field of pain and death"24 is perhaps a little hyperbolic, but the sobering gist of his argument remains relevant. When we scrutinise judicial reasoning, the explanations given for one important type of governmental action, we are manifesting a concern for the robustness of our freedom. Critically scrutinising judicial analysis is not merely a concern with the elegance of reasoning on arcane points of law. It matters to all of us, and the task should be taken very seriously indeed. For career legal scholars, all of this underscores some of the specific responsibilities that accompany the university's statutory mandate to be the conscience and critic of society. ${ }^{25}$ These responsibilities can also inform our classroom practice. They urge us to integrate our concerns with the rule of law with the basic apparatus of classroom discussion: careful and critical scrutiny of judicial reasoning connects the rule of law to technical analysis and skills development.

\section{TORTS IN THE CLASSROOM}

The outcome of any case is likely to have serious consequences for the parties involved - either directly or for their insurers, with consequent effects on the size of premiums both for them and for other policyholders. People expect to understand the reasons for decisions. In this sense, tort law supports no special pleading. For parties to any kind of dispute, it is important that courts do a good job. Disinterested participation in the collegial dialogues that go on between academics, the courts and other branches of government, the private sector and civil society - with the aim of helping

24 Robert M Cover "Violence and the Word" (1986) 95 Yale LJ 1601 at 1601 (footnote omitted).

25 According to the Education Act 1989, s 162(4)(a)(v), the characteristics New Zealand universities are expected to manifest include having "accept[ed] a role as critic and conscience of society". 
legal work to be as good as it can be - describes much of the endeavours of many professional legal scholars in any number of fields.

What makes torts seem just a little different - especially in the context of the second-year curriculum? A tort is a judicially-created and, for the most part, judicially-sustained, legal norm. ${ }^{26}$ Because the imposition of tort liability is grounded neither in the will of the parties nor, explicitly, in the will of the people, courts cannot rely on external sources of legitimacy. Torts are grounded purely in legal principle, or legal principle that crystallises as precedent. They occupy a space at the intersection of principle, precedent and societal expectations. The essential point of a foundational case such as Donoghue v Stevenson is that liability may be imposed upon the defendant without any express undertaking of responsibility by that defendant to that plaintiff. The same is true of our building cases ${ }^{27}$ according to which liability can be imposed to subsequent purchasers; strangers to the original contract. Even where the "assumption" of responsibility is said to be an element of the negligence action, we know that in negligent misstatement cases, at least, this really means "imposition" of responsibility. ${ }^{28}$ Similar points might be made of the ancient torts - assault, battery, false imprisonment and so on. Consistent with the common law's hierarchy of foundational norms, these torts give expression to common law commitments to the sanctity of the person, to physical integrity and basic liberty interests, and so on. ${ }^{29}$ While norms are articulated in many other contexts including legislation, human rights instruments and domestic constitutions, they do not animate the tort liability theory. If an unwanted kiss or unauthorised imprisonment are torts, this reflects judgemade principles, shaped over many generations, that they be regarded as such. Liability that arises in tort may be consistent with expressions of fundamental values articulated in other legal contexts, but the latter do not provide the source of the liability theory.

It is important not to overstate the point. ${ }^{30}$ In contract, for example, the idea that a meeting of minds can give rise to an enforceable set of promises is itself a judge-made principle, as is the conceit that the parties' actions objectively manifest an intention to be bound, even if that was the

26 Legislative action can also be understood as "sustaining" the existence of tort-based liability. See for example Body Corporate No 207624 v North Shore City Council [2012] NZSC 83, [2013] 2 NZLR 297 [Spencer on Byron] at [98]-[107], where McGrath and Chambers JJ read the Building Act 1991 as countenancing, indeed strengthening, the common law foundation for liability for negligent building inspection.

27 See for example Bowen v Paramount Builders (Hamilton) Ltd [1977] 1 NZLR 394 (CA).

28 Attorney-General v Carter [2003] 2 NZLR 160 (CA) at [22]-[25].

29 See Jason NE Varuhas "The Concept of 'Vindication' in the Law of Torts: Rights, Interests and Damages" (2014) 34 Oxford J Legal Studies 253.

30 See for example Andrew Robertson "On the Distinction between Contract and Tort" in Andrew Robertson (ed) The Law of Obligations: Connections and Boundaries (Cavendish Press, London, 2004) 87. 
furthest thing from their minds. ${ }^{31}$ Even so, while modern contract law also relies on judicially created and sustained legal norms, we rationalise the imposition of liability as an expression of individual will. So doing, it aligns with fundamental commitments of liberalism, even if, as many distinguished scholars have pointed out, modern contract law has much to do with imposed obligations, not merely obligations to which the parties have specifically agreed. ${ }^{32}$ But the basic idea that contracts give expression to parties' intentions offers contract a stronger conceptual foundation than is enjoyed by tort. Hence the priority of contract in civil obligations, which remains firmly in place despite the occasional spirited objection. ${ }^{33}$

How does any of this play out in the torts classroom? Professor Atkin has made it quite easy for New Zealand tort law teachers to do well. Together with his co-author, Professor Geoff McLay, another of my Victoria colleagues, Bill has provided New Zealand academics with an excellent casebook, Torts in New Zealand, now in its fifth edition. ${ }^{34}$ Based on decades of classroom practice by two very experienced torts teachers, this book extracts key passages from leading cases from New Zealand and cognate jurisdictions, and punctuates them with carefully crafted and insightful notes and questions. Every torts teacher who adopts the book will make his or her amendments and adjustments in order to make the torts classes his or her own (I have certainly done this). Even so, this text provides a sturdy foundation.

Of all the areas of tort law, negligence probably provides the best vehicle for helping students with the task of critically evaluating judicial reasoning, and to explore some basic questions about what the law is doing when it recognises and imposes legal duties. From a teaching perspective, Donoghue $v$ Stevenson is a gift, to the extent that it allows us to confront some fundamental questions about the scope of civil obligations. So doing, it invites us, and invites teachers of law to invite their students, to ask some very basic questions about who we are and what we value. Are we really neighbours? Are we atomised individuals? Or is all this contextual: are we at times one or the other, or both? Here are some of the supplementary questions students I ask students to prepare before coming to the first class at which we discuss the case:

31 Historically, the individual promise was treated as evidence of pre-existing obligations, rather than as the source of the obligation. See PS Atiyah The Rise and Fall of the Freedom of Contract (Clarendon Press, Oxford, 1985) at 143-145.

32 See for example David McLauchlan "The Contract that Neither Party Intends" (2012) 29 JCL 26; and David McLauchlan "The New Law of Contract Interpretation" (2000) 19 NZULR 147.

33 See for example the dissent authored by Thomas $\mathrm{J}$ in $R M$ Turton \& Co (in liq) v Kerslake, above $\mathrm{n} 6$ (criticising the majority for according insufficient weight to the principle of concurrent liability in tort and contract, but, more profoundly, noting the influence on common law thinking of what his Honour described, at [104] and [154], as the "lawyer's deep-rooted but misplaced deference to the primacy of contract").

34 Bill Atkin and Geoff McLay Torts in New Zealand: Cases and Materials (5th ed, Oxford University Press, Auckland, 2012). 
... 3. Why was the result in this case not blindingly obvious? Assuming that Mrs Donoghue could establish the facts to substantiate her claim, what was there left to dispute?

4. Lord Atkin said: "I do not think a more important problem has occupied your Lordships in your judicial capacity...". Really? This was a case about a snail in a bottle whose appearance in a dessert and partial consumption allegedly caused the appellant to get a shock and a dose of gastroenteritis. Doubtless this was awful for the appellant, but was the case really so important? Try to articulate why Lord Atkin might have thought so.

5. When thinking about the previous question, try to identify the differences in the ways that Lords Atkin and Buckmaster think the economy should be organised, and their thinking about the law's role in that organisation. ...

The first of these questions is meant to start students thinking about the work that the duty concept performs in negligence law. Many students tend to think that the duty analysis is about expanding liability: they struggle to recognise the important limitative role it plays - at least in the Anglo tradition. ${ }^{35}$ In the classroom, this point is explored further by asking a question along these lines: "Let's assume Mrs Donoghue could establish all the elements of her claim: that there was a snail, that she did become ill, that this was caused by the snail being in the bottle, that this was a result of carelessness by the manufacturer, and so on. What makes the defendant liable?" And then: "Is it a statute?" "Is it because of any agreement between the parties?" "Is it because of any agreement with any other party?", and so on. Such questions are designed to stimulate students' thinking about sources of law and, as a subset of this, sources of legal duties. Question four persists with these ideas, this time opening up a discussion of the connection between principle, morality, societal commitments, and doctrine: how does the biblical admonishment to love our neighbour get transformed into a legal principle that we must not injure our neighbour? ${ }^{36}$ And in a modern

35 In state jurisdictions within the United States, for instance, the duty concept appears seldom to be accorded the same prominence as it enjoys in New Zealand tort law. As a broad generalisation, in United States state jurisprudence, a duty tends to follow from the creation of risk. See John L Diamond, Lawrence C Levine and Anita Bernstein Understanding Torts (4th ed, LexisNexis, New Providence, 2010) at 106. Changes to New Zealand's procedural law might have the same practical effect here. If in a novel case, a strike out will seldom be considered appropriate (see Couch v Attorney-General [2008] NZSC 45, [2008] 3 NZLR 725 at [33] and [40]; Spencer on Byron, above n 26, at [4]). It may become more difficult, in a practical sense, for the duty concept to be deployed as a limiting factor (without going to the expense of developing a much fuller factual record).

36 This question about the salience of ethical principles is not mere idle philosophising. Rightly or wrongly, it found expression at the doctrinal level in, for instance, Brooks $v$ Commissioner of Police of the Metropolis [2005] UKHL 24, [2005] 1 WLR 1495, where Lord Steyn, elaborating on the enduring relevance of Hill v Chief Constable of West Yorkshire [1989] AC 53 (HL), said at [30]: "I have no doubt that it would be decided in the same way. It is, of course, desirable that police officers should treat victims and witnesses properly and with respect ... But to convert that ethical value into general legal duties of care on the police towards victims and witnesses would be going too far." 
pluralistic polity, why is that the apparent source of our obligations to each other? Question five aims to provoke some basic questions about the law's role in societal organisation. Donoghue v Stevenson presents a rich context within which to explore these questions. The leading speeches of Lords Buckmaster and Atkin reveal two very different versions of the good life: the first valorising individual responsibility, self-sufficiency and free will; the latter eschewing atomised individualism in favour of reciprocity of obligations, ${ }^{37}$ connectedness, mutuality - conflicting commitments that continually play out in the political arena today. Donoghue $v$ Stevenson also provides a context for students to understand how these tensions can be reflected in doctrinal commitments. More demographically minded teachers might see fit to mention some of the new work being done on New Zealand's population make-up, ${ }^{38}$ and growing concerns for what the significant changes we are witnessing might mean for our social policy. What, for example, does it mean to be "neighbours," and what does it mean for the common law principles distilled from this idea, when our major urban areas have become what demographers describe as "superdiverse" ? ${ }^{39}$ In the modern polity, what might be the respective roles of externally imposed obligations on the one hand and obligations we agree to be burdened with on the other? Contrariwise, a pragmatic sideward glance at the Consumer Guarantees Act 1993 shows how obligations in the products liability context are largely taken for granted as expression of the general will. Life for New Zealand consumers could be quite grim without them.

Other parts of the torts cannon also provide wonderful opportunities to explore questions such as these. Take Sturges v Bridgman, a nuisance claim brought by Dr Octavius Sturges against Fredrick Horatio Bridgman, confectioner to Queen Victoria. ${ }^{40}$ While Sturges $v$ Bridgman does not quite fit the model of the schematised torts case, in that the principal remedy sought was an injunction, this distinction sometimes seems superficial. In many cases, an injunction can be functionally equivalent to a transfer of wealth from one party to another. It will be recalled that Bridgman was the incumbent, and Sturges was the newcomer. Sturges' premises adjoined Bridgman's. The problem was caused by Bridgman's machines, two sixteen-inch mortars that were located close to the section of Sturges' garden where he had located his consulting room. Ronald Coase famously used the case to illustrate ideas about the irrelevance of rules requiring the internalisation of externalities in

37 See for example George Fletcher "Fairness and Utility in Tort Theory" (1972) 85 Harv L Rev 537. The very specific sense in which Professor Fletcher deployed the concept of reciprocity is beyond the scope of this article.

38 See for example Paul Spoonley and Catherine Taiapa Sport and Cultural Diversity: Responding to the Sports and Leisure Needs of Immigrants and Ethnic Minorities in Auckland (Report prepared for the Auckland Regional Physical Activity and Sport Strategy, 2009) at 10-16 (describing the phenomenon of "superdiversity", especially in Auckland).

39 See Spoonley and Taiapa, above n 38.

40 Sturges $v$ Bridgman (1879) 11 Ch D 852 (CA). 
circumstances of perfect information and low transaction costs, ${ }^{41}$ a set of claims subjected to withering critique by Professor Brian Simpson, who characterised as "fanciful"42 the idea that parties such as these, with incompatible and strongly held positions, will bargain toward an efficient solution. Simpson speculates that, given the actual parties and their actual situations, it would be "astonishing" if either party were motivated to offer the other party a sum of money to change his ways ${ }^{43}$ - at least not an amount that would achieve anything remotely resembling the holy grail of economic efficiency.

While it is too much to ask second-year law students to engage in any rigorous evaluation of the relevance of the Coase theorem to private nuisance law, the general lesson here is nevertheless important, and can provoke some useful classroom discussion. To be sure, the occasional party to a nuisance dispute might well be expected to buy out the other one. But when such parties do not, or will not, or cannot be expected to do so, the law will very likely be called upon to intervene assuming the parties can afford it - drawing on practical reasoning that, often appropriately, does not always have recourse to principles of economic efficiency. ${ }^{44}$ For second-year torts students, though, a case such as Sturges $v$ Bridgman distils some opportunities for other important lessons. The classroom discussion might begin with a set of questions along the following lines: "Mr Bridgman got there first, didn't he? Surely it's not fair that he should be required to change his way of doing business just because a new guy buys into the neighbourhood and then objects to the noise." (Nods in agreement all around.) This leads us to the key idea pursued by the Court of Appeal in the case: that an incumbent should not be able to hold up changes in land use in the surrounding neighbourhood. Or, put another way, being first in time does not give one the right to affect the use and enjoyment of all other property in the vicinity. Because it would limit the rights of neighbouring landholders to use their property in reasonable ways, allowing Mr Bridgman's activities to continue would be the equivalent of granting him rights over his neighbours' land, rights for which he has not paid. For one landowner to be required to internalise the negative externalities produced by a noisy

41 RH Coase "The Problem of Social Cost" (1960) 3 JL \& Econ 1, reprinted in RH Coase The Firm, the Market and the Law (Chicago University Press, Chicago, 1988) 95.

42 AW Brian Simpson "Coase v. Pigou Reexamined" (1996) 25 JLS 53 at 96.

43 At 88 .

44 As Professor Simpson noted, the very institution of private property can be, and very often is, an affront to any recognisable commitment to economic efficiency. Even if, as Harold Demsetz put it, "[a] primary function of property rights is that of guiding incentives to achieve a greater internalization of externalities" (Harold Demsetz "Toward a Theory of Property Rights" (1967) 57 Am Econ Rev 347 at 348) leading, so the story goes, to the creation of wealth, we do not necessarily know in advance who will be best at doing this. Descriptively, the proposition is also wrong. The law readily allows us to give away property to the profligate or incompetent (and, in New Zealand, such gifts are not even taxed). Simpson, above n 42, observed, at 88: "Despotic dominion is what the right of private property is all about, and it includes the right to behave in ways which make no contribution whatsoever to the national wealth." 
business is tantamount to allowing the latter to snaffle much of the value in the property interests of the former.

A well-crafted classroom discussion enables students to subject their initial instincts ("first in time, best right") to more testing critique. The carefully selected cases in Bill and Geoff's casebook also allow discussion of subsequent development in the case law - the problems that Sturges $v$ Bridgman subsequently caused for the cricket-loving English judiciary, ${ }^{45}$ and the way that equity can shape injunctive relief to balance the interests at stake in a more nuanced way. ${ }^{46}$ In the next edition, we should look forward to some carefully edited extracts from the United Kingdom Supreme Court's recent decision in Lawrence v Fen Tigers, ${ }^{47}$ a decision that directly confronts many of these questions, including questions concerning the conceptual intersection between private nuisance and property rights.

Law teachers are constantly asking students to extrapolate principles from facts, and then - and I think this truly gets to the "guts" of a torts class - to use those principles to analyse new facts. Different ways of doing so, and their accompanying advantages and pitfalls, are expertly explored in Professor Boyle's "Anatomy of a Torts Class" article. The article was written when critical legal studies was in its heyday, offering new ways to think about law, its role in society and the unspoken premises that underlie it. For full-time professional legal scholars, the critical legal studies movement opened up new strands of inquiry, and subjected tried and true ideas to intense scrutiny. In the teaching context, perhaps the essential challenge is this: whether, and if so when and how, to critique the structure and techniques of legal analysis, just as law students are embarking on a lifelong journey of trying to understand what traditional legal analysis is, and how to do it.

As any legal academic will tell you, what students most want - and what they persistently ask for - is structure. They like to learn formulae - "duty/breach/causation/damage"; "reasonable foreseeability of harm/proximity/policy"; "the intentional tortsfeasor is liable for all damage directly caused by the breach", ${ }^{8}$ and so on - through which "material facts" can be "shoved", on the way to positing a "solution" to the hypothetical du jour. In the duty of care context, for example, many students really do not really like it - indeed, I suspect some do not believe it - when one directs their attention to expressions of resistance to easy formulaic approaches in novel cases. To take one of many examples, Henry and Keith JJ observed in Turton v Kerslake: "As succeeding cases have demonstrated, the search for any single formula which will serve as a general test of liability in this

45 Miller v Jackson [1977] QB 966 (CA).

46 Kennaway v Thompson [1981] QB 88 (CA).

47 Lawrence v Fen Tigers Ltd [2014] UKSC 13, [2014] AC 822.

48 Compare Mayfair Ltd v Pears [1987] 1 NZLR 459 (CA). 
area inevitably causes difficulties"; 49 their Honours then quoted Lord Oliver's characterisation of the search for such a general test as akin to pursuit of a "will-o'-the-wisp". ${ }^{50}$

In the classroom, there is a constant need to acknowledge students' need for certainty while at the same time being honest about the manner in which doctrine evolves in the light of new facts and new problems, for all the anxiety this can provoke in the minds of second-year law students. Later, we hope that this anxiety will be transformed into a level of comfort with uncertainty - and an understanding that an appreciation of legal uncertainty will, where relevant, enable them one day to assist their clients with the crucial task of assessing risk.

Even so, it is these aspects of negligence law, the duty of care concept in particular, that make it such a useful teaching vehicle; one that helps students refine their skills of critical analysis. For example, I find it useful to move immediately from Donoghue $v$ Stevenson to cases that require a more testing analysis of the applicability of the neighbourhood principle. Again, I supplement the Atkin/McLay textbook with a set of questions that I ask students to prepare before the class at which Home Office v Dorset Yacht ${ }^{51}$ is discussed:

1. Why didn't the House of Lords simply "apply" Donoghue v Stevenson? What would a straightforward application of Donoghue $v$ Stevenson have been like? And isn't it obvious, based on Lord Atkin's neighbourhood principle, that a duty of care should exist in these circumstances?

2. Were there issues raised in this case that were not implicated in Donoghue $v$ Stevenson? If so, how were they resolved? ...

4. In the Court of Appeal, Lord Denning MR observed:

Many, many a time has a prisoner escaped - or been let out on parole - and done damage. But there is never a case in our law books when the prison authorities have been liable for it. No householder who has been burgled, no person who has been wounded by a criminal, has ever recovered damages from the prison authorities such as to find a place in the reports. The householder has claimed on his insurance company. The injured man can now claim on the compensation fund. None has claimed against the prison authorities. Should we alter all this? I should be reluctant to do so if, by so doing, we should hamper all the good work being done by our prison authorities.

For the purposes of the duty analysis, what significance, if any, should be accorded to the datum to which Lord Denning referred in the first few sentences?

49 RM Turton \& Co (in liq) v Kerslake, above n 6, at [7]. There are many other illustrations of this point. See, for example, the important comments about the significance of "judgment", "not formulae" in novel duty cases in South Pacific Manufacturing Co Ltd v New Zealand Security Consultants \& Investigations Ltd [1992] 2 NZLR 282 (CA) at 294.

50 Caparo Industries PLC v Dickman [1990] 2 AC 605 (HL) at 633.

51 Home Office v Dorset Yacht Co Ltd [1970] AC 1004 (HL). 
5. Does the House of Lords articulate a test for the duty of care that is (1) tailored to the situation in this case; and (2) different from the duty test articulated by Lord Atkin in Donoghue v Stevenson?

The point of all of this is a straightforward one, albeit one that second-year students find very challenging. The basic task, more easily described than executed, is to get students to see how new facts contest the continuing relevance of legal principles articulated in the context of other facts. Many students expect always to be able to ram new facts through "tests" derived from older cases, not realising that context - the messy realities of the lives of people and firms coming to the law to help resolve new kinds of conflicts - is everything. At this point in the torts syllabus, the key question to be teased out in the discussion is this: should it matter, when analysing the duty of care question, that Donoghue v Stevenson did not concern the imposition of liability on one party for the deliberate wrongful acts of another party, and, moreover, was solely concerned with private parties and no government action was involved?

The former point can also be developed in the context of the difficult decision of the House of Lords in Smith $v$ Littlewoods. ${ }^{52}$ In the following extract from the students' reading assignment for that case, a further elaboration of these themes will be apparent:

1. If one were simply to apply the Donoghue $v$ Stevenson duty test to the facts of this case, would one acknowledge the defendant owed a duty of care to prevent a third party from causing harm to the plaintiff's property? Why did their Lordships not do this? ...

5. In what circumstances would a duty of care be owed to neighbours to prevent damage caused by a third party? ...

8. Note Lord Goff's concern to not impose an "unreasonable curb on the ordinary enjoyment of ... property." ... Was his Lordship sufficiently solicitous of the ordinary enjoyment of the plaintiff's property?

This kind of analysis provides the conceptual framework for the discussion of the important New Zealand case, Couch v Attorney-General, ${ }^{53}$ in which many of these issues are also ventilated. In later editions of the casebook, we might expect to see carefully selected extracts from Michael $v$ Chief Constable of South Wales Police, in which the United Kingdom Supreme Court had the opportunity to consider a claim in negligence for mishandling an emergency call by the family of a victim of a fatal stabbing. ${ }^{54}$

52 Smith v Littlewoods Organisation Ltd [1987] AC 241 (HL).

53 Couch v Attorney-General, above n 35.

54 Michael v Chief Constable of South Wales Police [2015] UKSC 2, [2015] 2 WLR 343 (rejecting, by a majority, the claim in negligence, the analysis draws on Hill v Chief Constable of West Yorkshire, above $\mathrm{n}$ 36). 
The former theme - whether, and if so in what circumstances, it is appropriate to impose liability on a government actor - can be explored in the context of cases such as Dutton v Bognor Regis Urban District Council, ${ }^{55}$ Anns v Merton London Council,,${ }^{56}$ Takaro Properties v Rowling 57 and Attorney-General v Prince and Gardner, ${ }^{58}$ amongst others. In the law enforcement context, it might be useful to compare this statement in Dorset Yacht, where Lord Reid confronted the argument that the imposition of a duty of care would have a chilling effect on the work of correction service personnel, an argument that apparently had purchase in the New York state law context: ${ }^{59}$

It may be that public servants of the State of New York are so apprehensive, easily dissuaded from doing their duty and intent on preserving public funds from costly claims that they could be influenced in this way. But my experience leads me to believe that Her Majesty's servants are made of sterner stuff. So I have no hesitation in rejecting this argument. I can see no good ground in public policy for giving this immunity to a government department. I would dismiss this appeal.

with this one from the more recent House of Lords decision in Brooks v Commissioner of Police ${ }^{60}$

Whilst focusing on investigating crime, and the arrest of suspects, police officers would in practice be required to ensure that in every contact with a potential witness or a potential victim time and resources were deployed to avoid the risk of causing harm or offence. Such legal duties would tend to inhibit a robust approach in assessing a person as a possible suspect, witness or victim. By placing general duties of care on the police to victims and witnesses the police's ability to perform their public functions in the interests of the community, fearlessly and with despatch, would be impeded. It would ... be bound to lead to an unduly defensive approach in combating crime.

What has changed? Is it the context? The empirics? The "zeitgeist"? Basic assumptions about the relationship between the citizen and government? ${ }^{61}$

With the government actor cases, there are useful crossovers with the building cases, which can be taught either as a vehicle for exploring the relevance of the "economic" character of the loss (and

55 Dutton v Bognor Regis Urban District Council [1972] 1 QB 373 (CA).

56 Anns v Merton London Borough Council [1978] AC 728 (HL).

57 Takaro Properties Ltd v Rowling [1986] 1 NZLR 22 (CA).

58 Attorney-General v Prince and Gardner [1998] 1 NZLR 262 (CA).

59 Home Office v Dorset Yacht Co Ltd, above n 51, at 1033.

60 Brooks v Commissioner of Police [2005] UKHL 24, [2005] 1 WLR 1495 at [30].

61 In some syllabi, this line of cases would provide an opportunity for analysis and discussion of a very rich line of cases, including Hill v Chief Constable of West Yorkshire, above n 36; Osman v United Kingdom (2000) 29 EHRR 245 (ECHR) (and Osman v Ferguson [1993] 4 All ER 344 (CA)); and Jane Doe v Metropolitan Toronto (Municipality) Commissioners of Police (1998) 160 DLR (4d) 697 (ONCJ). 
the specific New Zealand take on that issue) or the relevance of the statutory context within which government actors make the kinds of decisions that might be characterised as negligent - or both. Students have the opportunity to explore how legal tests evolve and change in response to new facts and new concerns. They are helped to understand how so much legal analysis involves asking the right questions, working out what is relevant and what is not - and to understand why a lawyer who simply "applied" Donoghue v Stevenson, who treated the principles in that case as an immutable structure for analysing all duty claims, would miss what was really at stake in new factual contexts.

Underlying all of this, as has been suggested earlier, is a concern with the legitimacy of judicial activity. What does it mean for a court to tell an elected branch of government that it needed to take better care so as not to cause harm to an individual within its jurisdiction, when taking reasonable care might mean shifting resources from one area of service delivery to another? Can judicially imposed warranties of quality really be justified, and does it make a difference whether functioning markets for such warranties have ever existed? And what might be the effect of decisions, either way, on the emergence of markets for such warranties? When does the requirement that we act to prevent third parties from harming others intolerably burden our freedom? As we encourage our students to discuss, critique and defend the reasoning in the cases, we are helping them with the important task of legal skills development, as we help them acquire a basic facility with techniques of legal analysis, incrementally building upon this foundation as the weeks go on. At the same time, we are asking them to engage with deeper questions about social, economic and political organisation - about relationships between the individual, the state, collective organisations and civil society.

These are familiar questions, and there are diverse views on how they should be answered, as between the judiciary, both within and between different jurisdictions, between legal scholars and between practising lawyers. There will certainly be different views held amongst students in any torts classroom. As university-level teachers, our duty is to ensure that there is space for these views to be ventilated and constructively critiqued in a supportive and respectful environment of higher learning. We would be failing in our statutory commitment to take on the role of conscience and critic of society ${ }^{62}$ if we did anything less. We would also be falling short in terms of any respectable commitment to the rule of law. There are many reasons why scrutinising legal reasoning is an important undertaking - but concern with the robustness and strength of the connection between the rule of law and the quality of the justifications for state action is surely an important one. Universities have a critically important role in evaluating the justifications that are proffered for state action. In the classroom, one of our core responsibilities is to help our students understand why this matters, to be able recognise the implications for individuals and for society, and to equip them, in a way that is appropriate for this early stage of their lives in the law, with the kind of knowledge and skills that are necessary to participate in this important work.

62 See Education Act 1989, s 162(4)(a)(v). See above n 25. 


\section{CONCLUSION}

In Smith v Littlewoods, Lord Goff famously said that the "judicial function" can be "epitomised as an educated reflex to facts". ${ }^{63}$ For career legal academics, his Lordship's observation distils a cluster of challenges and responsibilities that are as inspiring as they are difficult. As professional legal scholars, one of our key tasks is to help our students refine their reflexes to the real-life facts that will confront them in their professional lives - that is, to become more "educated", in the sense suggested here. We want every one of our students to know what questions to ask in the light of new problems presented by the public served by the legal profession. We want our students to have "reflexes" that are sufficiently "educated" to have been the kind of lawyer who, for example, said of the facts in Dorset Yacht: "Hang on a minute: the claims of these yacht owners aren't at all like Mrs Donoghue's claim. Here, there are third party wrongdoers, and, what's more, the defendant is performing an important governmental role." That line of thinking would be partly a result of doctrinal knowledge - after all, the Australian High Court decision of Smith v Leurs ${ }^{64}$ was critical to their Lordships' thinking about third party issues - but it would also come from thinking very carefully about the implications of different facts. As we know, these concerns did not win the day, but that kind of lawyer was at least asking some of the right questions - and the same would be true of counsel for the yacht owners who anticipated these concerns and was able to develop responses to them. Or, to take an example from closer to home, the New Zealand building inspection cases: "Wait right there! There are many differences between the regulation of the New Zealand housing market and that in England and Wales; perhaps this makes a difference to our approach to duties of care, both for builders and territorial authorities." Whether these differences remain salient is a contested question, as is underscored by the differing approaches of the dissent and the majority in a case such as Spencer on Byron - both of which were, with respect, insightful, carefully reasoned and compelling. ${ }^{65}$

We want our students to become the kinds of legal professionals who can recognise new issues provoked by new facts, and, drawing on their knowledge and understanding of extant doctrine and of the world around them, to be the among the first to be raising these kinds of questions, and, most importantly, to be asking them even before they come to be analysed in published opinions. Of course, most of us, I hope, have the humility not to think that the task will not be completed even after four years' intense study of the law, nor to believe that achieving a more "educated reflex to facts" in the sense described by Lord Goff remotely describes the complete suite of skills required for good lawyering. We constantly tell our students, and ourselves, that the journey will be a lifelong endeavour, and that the profession of law is peopled by dedicated, expert and inspiring

63 Smith v Littlewoods Organisation Ltd, above n 52.

64 Smith v Leurs (1945) 70 CLR 256.

65 Spencer on Byron, above n 26. 
individuals from whom they (and we) can always learn. A United States professor interviewed for a book on legal pedagogy published by Harvard University Press in 2013 perfectly captured these kinds of aspirations. She said: "I am privileged to participate in what I hope is the transformative process of helping students to reach new understandings of subject, self, and society." 66 It is a process, we are all participants - and, yes, it is a privilege.

Bill is far too modest to characterise his own work in such highfaluting terms, but those of us who have witnessed his teaching and research supervision first hand understand that this is exactly the kind of thing he does. It is refreshing that professional legal scholars such as Bill continue to pursue excellence in teaching, research, and public service despite persistent pressure to eschew such lofty aspirations and to succumb to the totalising disciplines of externally imposed metrics, as universities are encouraged to become more and more like state delivery agencies. When one closely observes the work of an expert scholar-teacher such as Bill, one can readily see that his achievements have demanded unswerving commitment and dedication over many, many years. This kind of work can be exhausting, but also exhilarating and inspiring. In the current environment, it can also take a lot of guts.

66 Michael Hunter Schwartz, Gerald F Hess and Sophie M Sparrow What the Best Law Teachers Do (Harvard University Press, Cambridge (Mass), 2013) at 301. 